\title{
Casing while Drilling - a Viable Alternative to Conventional Drilling
}

\author{
Ion Foidaş ${ }^{1, *}$, Dan-Paul Ştefănescu ${ }^{1}$, and Mihai Serbancea ${ }^{2}$ \\ ${ }^{1}$ Lucian Blaga University of Sibiu, E. Cioran 4, Sibiu, Romania \\ ${ }^{2}$ Weatherford Atlas GIP S.A, Clopotei 2, Ploiesti, Romania
}

\begin{abstract}
Mankind's increased requirement for and dependence on energy resources, including the resources resulting from discovery and development of new hydrocarbon commercial reservoirs involves the use of new technologies such as optimization of the drilling process by reducing the non-productive time, the costs and the risks. Casing while drilling involves elimination of classical drilling string by using the casing string both for transmission to the bit of the mechanical energy and for circulation of drilling fluid into the well. Although there is a number of technical or perception barriers related to the use of casing drilling, the important benefits of this technology related to reduced drilling time and problems associated to the drilling string make it an increasingly viable alternative to conventional drilling. The experience in applying this technology has proven that it can reduce the time of well execution and sometimes it lowers the costs in relation to drilling depth.
\end{abstract}

\section{Introduction}

Considering the information provided by the International Energy Agency [1], the global natural gas demand increased continuously since 2009 , reaching 3757 billion $\mathrm{m}^{3}$, with the perspective of an increase up to $23 \%$ to $25 \%$ share of the global energy consumption in 2040.

The global natural gas demand increase is related, mainly, with a lower environment impact of this fuel as compared to other fossil fuels, especially in relation to air quality, as well as to greenhouse gas, as natural gas is the main substitute of coal in electricity generation industry, despite the higher risks implied by the explosive character of the natural gases [2].

Thus, "natural gas comprised 22\% of electricity supply globally in 2014. By 2060 this could change to anything between 17-32\% - an absolute increase of between 300-1500 bcm" [3].

In order to satisfy such demand, the gas producers plan drilling programs for exploration - in order to discover new gas reservoirs, and for production - in order to increase the gas production rate for reservoirs in production. To achieve such investment programs, considerable amounts are often allocated, amounts which are often spent before completing the program, due to complications and technical accidents occurred during drilling which might increase the final cost of the wells.

* Corresponding author: ion.foidas@romgaz.ro 
To reduce such unforeseen costs of the well drilling operations, more and more companies experiment and implement new drilling techniques and technologies which reduce the downtime, mitigate the risk and technical accidents while drilling.

Casing while drilling - CwD is one of the alternatives of controlled pressure drilling like Constant Bottomhole Pressure, Pressurized Mud Cap Drilling or Dual Gradient Drilling.

Casing while drilling is an alternative to conventional drilling using the casing as drilling string, drilling and casing the well simultaneously.

Although the casing while drilling technology was tested in the 1920 s, extensive use was possible only during the last decade, following the technical advancements [4]. The method was therefore proven as effective in reducing the overall drilling cost by reducing drilling time and the problems associated to the drilling string.

\section{Equipment used for casing while drilling}

The equipment used for casing while drilling can be either conventional with minimum additional equipment or specially configured drilling rig for this purpose.

The drilling rig has to achieve the main parameters of the drilling regime and consolidation of the well bore, comprising three essential systems: drive system, rotary system and circulation system.

For casing while drilling the surface casing drive systems have been adapted and improved allowing to run casing in hole, to circulate the drilling fluid and to rotate safely the casing on the derrick replacing the conventional tongs, eliminating the personnel from the dangerous area while making the connections, and the conventional links are operated remotely in order to eliminate the derrickman from the monkey board.

Surface Casing Drive Systems (Figure 1) can be used for a large range of casing size as they are designed to be externally clamped - for casings of small size (from $3 \frac{1 / 2}{\text { in to }} 9^{5 / 8}$ in), or internally clamped for casing larger than $9^{5 / 8}$ in, as they are controlled automatically by PLC from the driller cabin [4].

There are basically two methods for casing while drilling:

- rotate the casing from surface to send the torque to a bottom hole assembly that drills and cements;

- $\quad$ run in a retractable bottom hole assembly, run inside the casing, incorporating a bit and a reamer.

With respect to drilling by rotating the casing from the surface, eliminating the possibility to withdraw the bit, called for creating special drilling bits, with the same performances as the conventional bits. After reaching the desired depth these may serve as casing shoe being easy to mill with PDC bits after cementing - Figure 2 .

Usually inside the casing while drilling a float collar is fitted in order to cement immediately after reaching TD.

The float collar (Figure 3) is made of steel, almost equal to the resistance of the casing, its valve has to be resistant to the erosion of the drilling fluid, to the pumping pressure and to the pressure behind the casing.

Similar to the bits used for casing while drilling, the inner components of the float collar should be easily milled fully with PDC bits.

For cementing operations, wiper plugs (Figure 4) are used to create a barrier between the drilling fluid and the cement slurry. Depending on the well conditions, one or two plugs are used. These can be easily milled both by the rotary bit and by the PDC bit, having also a nonrotary profile that does not allow rotation during milling operations, reducing the operating time [4]. 


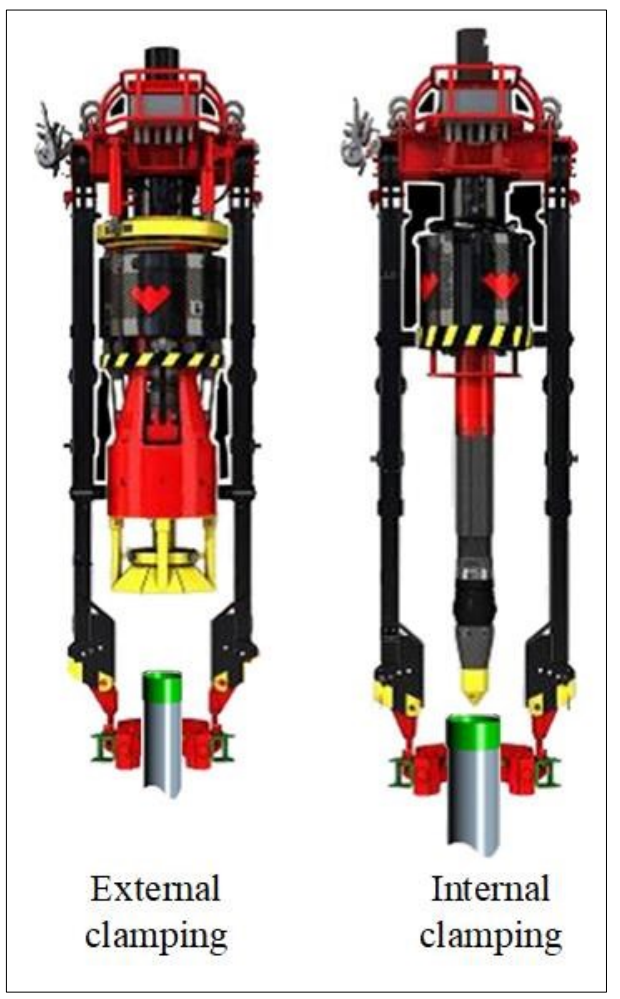

Fig. 1. Casing drive System [4].

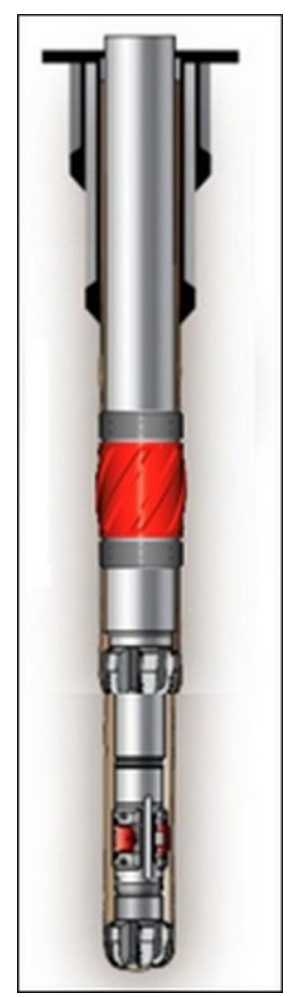

Fig. 2. Milling the drilling bit used for $\mathrm{CwD}$.

To maintain the well's track, to manage casing wear and lining-up casing during cementing the casing is fit with centralizers. It is recommended to use centralizers with rough surface and hard blades, non-rotating, made of zinc alloy, that are extremely durable during directional drilling with casing - Figure 5.

Casing threads are different from those used for conventional drilling to meet the different working conditions in the well. Therefore, the casing manufacturers developed a range of casings that satisfy the challenges and severe well conditions manifested during casing while drilling. These connections have to ensure torque resistance, adequate sealing capacity and fatigue strength.

In certain situations, casing while drilling calls for using a recoverable/retractable drilling system due to the need to replace the damaged equipment before reaching the casing depth.

Operators have to reach rapidly and efficiently the formations beneath the casing shoe and to recover the expensive tools used for a directional casing while drilling.

Casing while drilling uses a bottom hole assembly (BHA) that can be run in and retrieved by a wireline; its main elements are a bit and an under reamer at the bottom of casing string to drill a hole of adequate size to allow the casing to pass freely.

The BHA is attached to Drill-Lock Assembly (DLA) engaging axial lock and torsional lock, fixed in a nipple at the lower part of the casing string that can be retrieved by wireline without removing the casing from the well. The retrievable DLA rotates both the casing string and the drilling string and transfers compression and torque loading. It is recommended to use centralizers on the casing and to prevent wear of sleeves.

BHA may include other equipment necessary for performing almost any operation as a conventional drilling string. Conventional directional drilling tools (positive displacement motor, MWD) and LWD may be suspended below the casing shoe for directional drilling. 


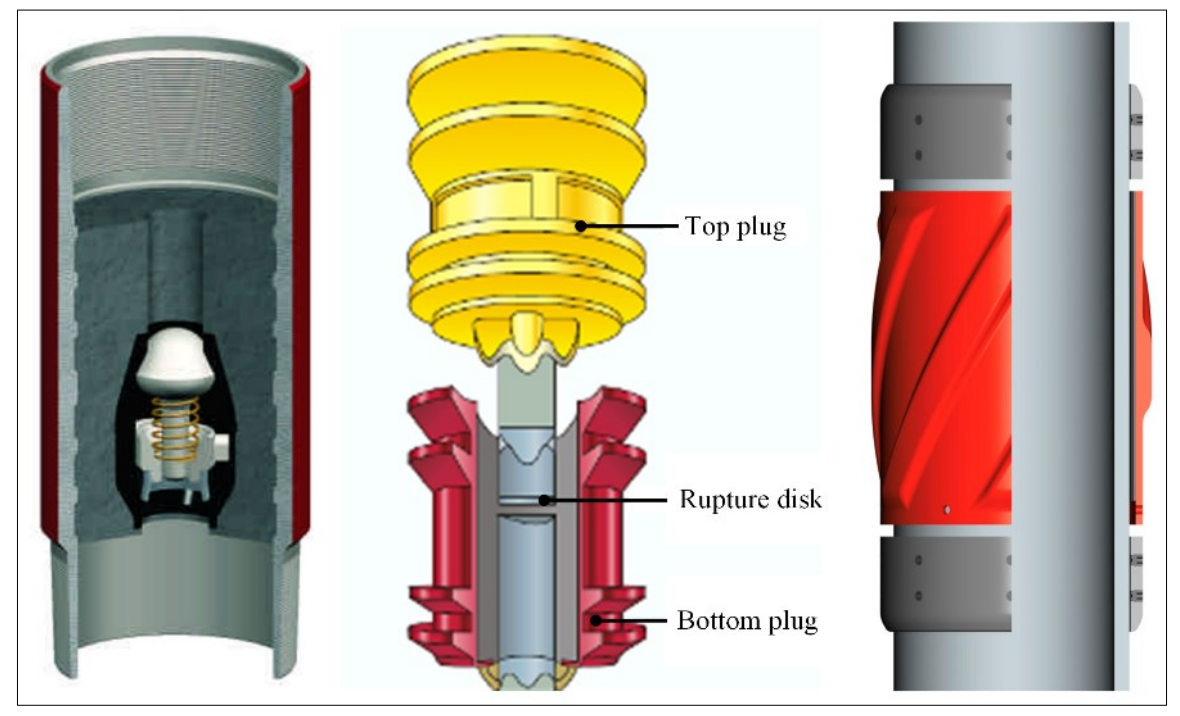

Fig. 3. Float collar [4].

Fig. 4. Wiper Plugs [4].

Fig. 5. Centralizer Sub [4].

\section{CwD Advantages}

Using $\mathrm{CwD}$ a lot of problems associated to conventional drilling are eliminated or reduced.

Among these problems, an important category is caused by the drilling string that may induce the following risks:

- twist off of the drill collar, kelly, drill pipe;

- drilling string sub-assemblies pull out of threads or unscrewing;

- drilling string getting stuck;

- drill pipe breaking or bending.

Other problems that can be avoided by casing while drilling are those associated to inserting casing in wells with bended or collapsed holes. Moreover, one can avoid problems caused by crossing formations that deteriorate due to long exposure to drilling fluids, problems associated to crossing unstable formations (borehole collapsing and overpull) or crossing formations with loss of circulation.

These issues are overcome by the so-called plastering effect generated by rotating the casing string in a small annular space causing detritus to enter the borehole wall, sealing the formation pores and strengthening the borehole walls [4].

As shown in figure 6, while drilling with a conventional drilling string the annular space is larger, casing while drilling reduces to minimum the annular space resulting in a more stable and sealed wellbore. Additionally, the annular ascending velocity of the drilling fluid through this annular space is high, improving detritus cleaning from the wellbore, and the rigidity of the casing string make a less tortuous hole, reducing the risk of key seats or mechanical sticking.

Another CwD advantage is total drilling time reduction by eliminating time and efforts implied by tripping casing string. Therefore, after reaching the depth for setting the casing, the drilling fluid is replaced by cement, the float collar being installed before drilling start.

Therefore, the operations performed before conventional casing and cementing are avoided, operations involving control tripping of the borehole to correct the overpulling areas, circulating for removing solids from the fluid from, performing electrometric operations, retrieval the bit by decomposing strings, inserting casing by filling the casing string at each casing section. 


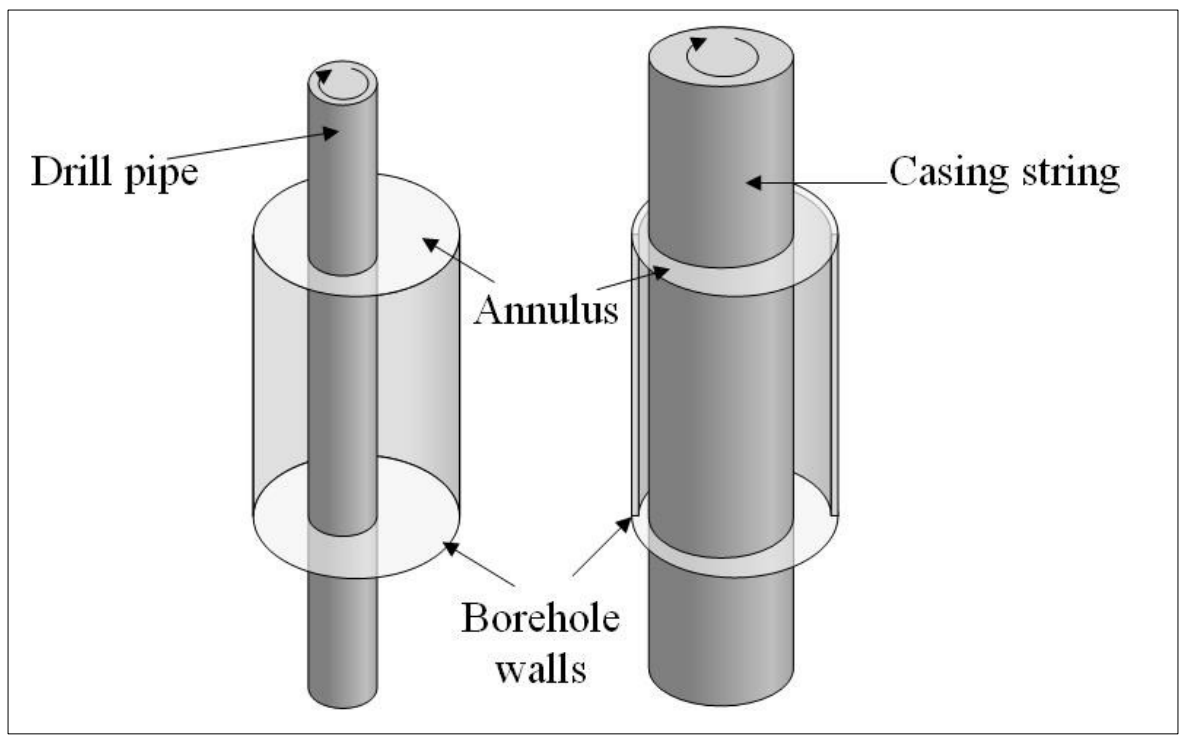

Fig. 6. Annular space size in conventional drilling vs casing while drilling.

\section{Casing design issues for CwD}

Boreholes are strengthened with steel casing screwed to each other. The regularly used casing is 6-12 m long, outer (nominal) diameter of $4 \frac{1}{2}-20$ in and has a wall thickness ranging from 5 to $15 \mathrm{~mm}$.

The purpose of casing a well is to:

- prevent wellbore collapsing;

- isolates such formations that create major difficulties for drilling (formation overpressure or easily breakable);

- $\quad$ provide a solid support for the surface facilities (preventers, christmas tree);

- transfer through the suspension system to the surrounding rocks the axial loading of the next casing sections or tubing and of surface facilities weight;

- to ensure sealing of layers containing different types of fluids and different pressures;

- to enable production under safety conditions;

The forces acting on the casing string are: tensile force, compression, outer and inner pressure -fig.7. In case of casing while drilling, additional forces act on the casing (fatigue, torque, buckling). Casing strength to these forces has to be known in order to set the profile of a casing.

Tensile force occurs because of the casing's own weight. If the tensile force reaches a critical value, equal to the casing's tensile strength, these will break in the weakest part.

Considering that the casing's connection tensile strength is different from casing body strength, the calculation has to be done for both elements so as to take into consideration the lowest values when setting the casing profile. Usually the lowest values of the breaking strength are at the connection point.

Outer pressure is given mainly by the hydrostatic column of the fluid behind the casing. Casing may collapse when the pressure is higher than its strength. To determine the critical pressure for casing manufactured according to API standards we have to consider the ratio between the nominal diameter $D$ and wall thickness $t$. 
The outer pressure that reaches on the inner casing wall the minimum yield point is given by the ratio (thick wall casing) [5]:

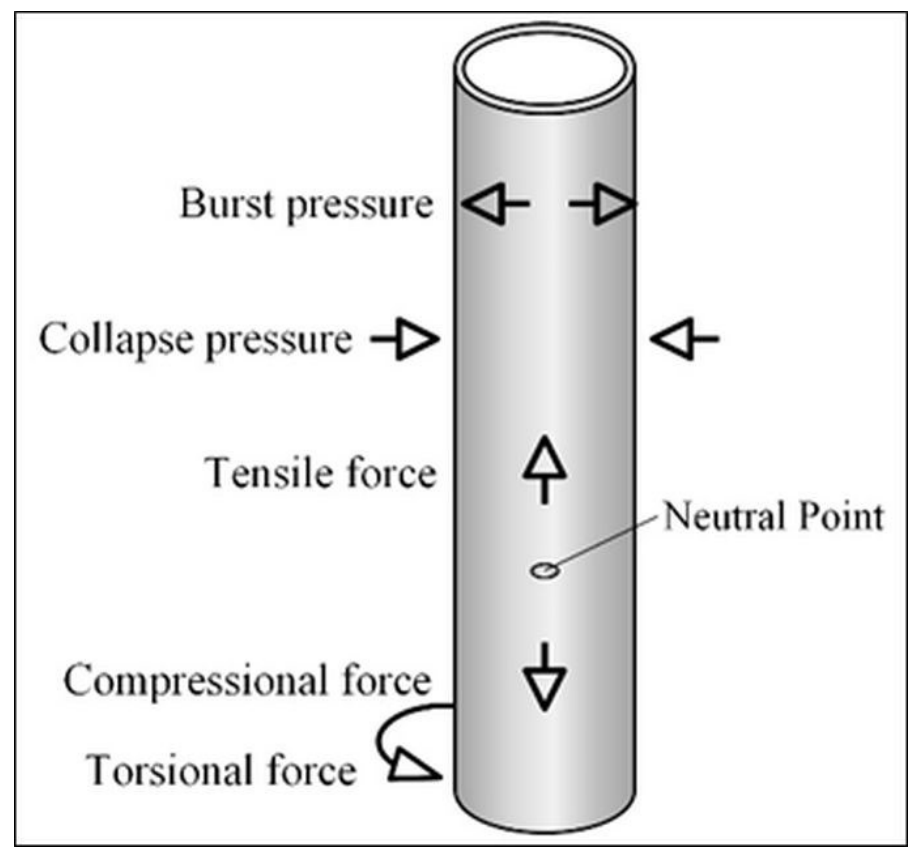

Fig. 7. Forces acting on casing.

where $\sigma_{c}$ is yield point;

$$
P_{e}=2 \sigma_{c}\left\lfloor\frac{D / t-1}{(D / t)^{2}}\right\rfloor
$$

$D$ - outside diameter;

$t$ - wall thickness.

Inner pressure is the casing fluid pressure, that can be the drilling fluid or the fluid from a layer opened while drilling. The strength to inner pressure can be calculated by using Barlow's formula [5]:

$$
P_{i}=2 \frac{\sigma_{c} t}{D}
$$

Torque at the drill bit at the bottom of the hole is the consequence of the cutting process and of the friction of the casing against the wall of the borehole and/or of the previously cased hole. Having the drill bit above the bottom hole, the torque resides only from friction of the casing. Casing while drilling torque is usually higher than at conventional drilling due to the friction forces acting on the contact point between the borehole walls and the casing, creating a strength moment with a vector direction opposite to the casing rotation. Thus, when the casing is rotating in the borehole placing a certain weight on the bit, the moment at the bit is much lower than the rotating moment at the surface. Therefore, the maximum torque at the surface sets the casing rotation limit and the increase of the drilling rate.

Fatigue results from the cyclic load at different stress levels considerably lower than the yield point of the casing material. Under continuous load, a small crack starts to spread from the high stress point along the casing breaking it.

Buckling results from the bending moments created by the casing-borehole geometry and the compressive load, thus making it unstable. If the compressive stress acting on the casing exceeds a certain value, the casing buckles into a helical or sinusoidal shape. 
After buckling, the casing leans against the borehole walls, thus the lateral stress from the contact point may cause wear and may lead to an increase of the moment required for rotation.

Taking into account the above-mentioned elements, following stages are necessary for sizing the casing string [5]:

- preliminary sizing for cracking and crushing;

- correct the profile set in the first stage by reducing the casing collapsing pressure under tensile forces;

- to check the casing and joints tensile resistance.

Other loadings have to be also considered [4]:

- bending with tongs during make-up;

- pull-out of the joint and slip crushing;

- corrosion and fatigue failure;

- pipe wear from running wireline tools and drill string.

To perform casing while drilling in safety conditions it is mandatory to apply during the design phase safety coefficients. The highest safety coefficients should be considered for tensile forces, in order to consider additional stress such as friction with the borehole wall, sticking trends, dynamic forces or buckling. With respect to tension a safety factor of $1.6-$ 1.8 is applied for the upper joint of casing [4].

In case of breaking and crushing, the coefficient can be lower, for breaking 1.1 and 1.0 and for crushing 0.9; the calculation hypotheses for such stress are less probable to be fulfilled [5].

\section{Risk considerations related to casing while drilling vs. conventional drilling}

Risk is defined as the exposure to an event that may occur to the detriment or benefit of a project or activity. It can be described as a combination between the probability that the risk occurs and the consequences of loss or gain [6].

Risk exposure, meaning the consequences, as a combination between probability and impact on an organization's previously set objectives [7], can be expressed by the following formula:

$$
\text { Risk exposure = Impact x Event Occurrence Probability }
$$

Therefore, risks can be classified depending on exposure: low, medium, high and very high risks.

Risk management is the systematic process for identifying, analyzing and responding to the potential risk of a project.

During the performance of a drilling project, drilling risks may occur related to geology, technical-operational issues or a combination of both. Objective difficulties are triggered by physical and chemical characteristics of rocks crossed by the borehole and characteristics of fluids contained in pores or cracks: the so-called difficult geological formations; the subjective issues are related to technology and procedure. As regards projects, all risks are identified, risk exposure is assessed by estimating the occurrence probability and the impact, so that by implementing an efficient risk management such risks are avoided or mitigated.

Table 1 and 2 show maps with the main risks that may occur during conventional drilling or casing while drilling. Estimating the risk occurrence probability is made for each project separately, based on a correlation wells and on the drilling technology and procedures used.

As a conclusion after comparing the two tables, casing while drilling might reduce or mitigate risks during drilling especially those related to the conventional drilling string, to maintaining borehole stability or circulation loss. 
Table 1. Conventional drilling risk map.

\begin{tabular}{|c|c|c|c|}
\hline $\begin{array}{l}\text { Potential } \\
\text { risk }\end{array}$ & Causes & Consequences & Risk mitigation measures \\
\hline $\begin{array}{l}\text { Circulation } \\
\text { loss }\end{array}$ & $\begin{array}{l}\text { Inadequate specific weight of } \\
\text { drilling fluid. } \\
\text { Drill string tripping-in speed } \\
\text { to high. }\end{array}$ & $\begin{array}{l}\text { Non-productive } \\
\text { times. } \\
\text { Additional materials } \\
\text { and services }\end{array}$ & $\begin{array}{l}\text { Drilling fluid treatment. } \\
\text { Use of blocking materials. } \\
\text { Placement of cement plug. }\end{array}$ \\
\hline $\begin{array}{l}\text { Drilling } \\
\text { fluid } \\
\text { gasification }\end{array}$ & $\begin{array}{l}\text { Pressurized formation. } \\
\text { Low density of drilling fluid. } \\
\text { String pull out, packed or } \\
\text { with high speed. }\end{array}$ & $\begin{array}{l}\text { Non-productive } \\
\text { times. Additional } \\
\text { consumption of } \\
\text { materials and } \\
\text { services. } \\
\text { Kicks. }\end{array}$ & $\begin{array}{l}\text { Continuous monitoring of } \\
\text { entry- exit fluid flow rates. } \\
\text { Drilling fluid weighting. } \\
\text { Fluid circulation through } \\
\text { degasifier. }\end{array}$ \\
\hline $\begin{array}{l}\text { Pack-offs, } \\
\text { collapse of } \\
\text { borehole }\end{array}$ & $\begin{array}{l}\text { Limestone swelling } \\
\text { Swabbing effect when } \\
\text { pressure under the bit is } \\
\text { reduced due to pulling the } \\
\text { drill string }\end{array}$ & $\begin{array}{l}\text { Non-productive } \\
\text { times. Additional } \\
\text { consumption of } \\
\text { materials and } \\
\text { services. }\end{array}$ & $\begin{array}{l}\text { Use of products to stabilize } \\
\text { the limestones. } \\
\text { Additional measures to } \\
\text { correct borehole. } \\
\text { Circulation to remove } \\
\text { detritus. }\end{array}$ \\
\hline $\begin{array}{l}\text { Stuck } \\
\text { casing } \\
\text { before } \\
\text { reaching } \\
\text { casing } \\
\text { depth }\end{array}$ & $\begin{array}{l}\text { Pack-off/ collapse of borehole } \\
\text { Differential sticking }\end{array}$ & $\begin{array}{l}\text { Non-productive } \\
\text { times. Additional } \\
\text { consumption of } \\
\text { materials and } \\
\text { services. } \\
\text { Well construction } \\
\text { compromised. } \\
\end{array}$ & $\begin{array}{l}\text { Measures to correct } \\
\text { borehole before casing. } \\
\text { Circulation to remove } \\
\text { detritus. } \\
\text { Casing reciprocation. }\end{array}$ \\
\hline $\begin{array}{l}\text { Drill string } \\
\text { stucks }\end{array}$ & $\begin{array}{l}\text { Pack-off/ collapse of borehole } \\
\text { Differential sticking } \\
\text { Drill string or drill bit pack } \\
\text { off }\end{array}$ & $\begin{array}{l}\text { Non-productive } \\
\text { times. Additional } \\
\text { consumption of } \\
\text { materials and } \\
\text { services. }\end{array}$ & $\begin{array}{l}\text { Stabilization of limestones. } \\
\text { Reduction of resting time } \\
\text { of string. } \\
\text { Circulation to remove } \\
\text { detritus. }\end{array}$ \\
\hline $\begin{array}{l}\text { Drill string } \\
\text { failure }\end{array}$ & $\begin{array}{l}\text { Drill pipes break off. } \\
\text { Threaded connections pull } \\
\text { out or break off. } \\
\text { Lost string. }\end{array}$ & $\begin{array}{l}\text { Non-productive } \\
\text { times. Additional } \\
\text { consumption of } \\
\text { materials and } \\
\text { services. } \\
\text { Compromised well. }\end{array}$ & $\begin{array}{l}\text { String control while run in } \\
\text { hole and pull out. } \\
\text { Using drill pipes in } \\
\text { accordance with well } \\
\text { requirements of wear and } \\
\text { tear. } \\
\text { Control of elevator, links, } \\
\text { rams, drilling cable. }\end{array}$ \\
\hline $\begin{array}{l}\text { Casing } \\
\text { failure }\end{array}$ & $\begin{array}{l}\text { Casing pull out from a } \\
\text { connection. } \\
\text { Casing collapse. } \\
\text { Break of casing. }\end{array}$ & $\begin{array}{l}\text { Non-productive } \\
\text { times. Additional } \\
\text { consumption of } \\
\text { materials and } \\
\text { services. } \\
\text { Well construction } \\
\text { compromised. }\end{array}$ & $\begin{array}{l}\text { Proper tightening of } \\
\text { connection. } \\
\text { Drilling fluid pumping at } \\
\text { each or every second } \\
\text { casing(s) run in hole. } \\
\text { Casing testing at surface } \\
\text { before RIH. }\end{array}$ \\
\hline $\begin{array}{l}\text { Keyhole } \\
\text { formation }\end{array}$ & $\begin{array}{l}\text { Sudden changes in direction } \\
\text { and bending of borehole }\end{array}$ & $\begin{array}{l}\text { Non-productive } \\
\text { times. Additional } \\
\text { consumption of } \\
\text { materials and } \\
\text { services. }\end{array}$ & $\begin{array}{l}\text { Drill string to be equipped } \\
\text { with blade corrector. } \\
\text { Well path control. }\end{array}$ \\
\hline
\end{tabular}


Table 2. Casing while drilling risk map.

\begin{tabular}{|c|c|c|c|}
\hline Potential Risk & Causes & Consequences & Risk mitigation measures \\
\hline $\begin{array}{l}\text { Loss of } \\
\text { circulation }\end{array}$ & $\begin{array}{l}\text { Inadequate specific weight of } \\
\text { drilling fluid }\end{array}$ & $\begin{array}{l}\text { Non-productive times. } \\
\text { Additional consumption of } \\
\text { materials and services. }\end{array}$ & $\begin{array}{l}\text { Drilling fluid treatment. } \\
\text { Blocking materials to be } \\
\text { used. }\end{array}$ \\
\hline $\begin{array}{l}\text { Drilling fluid } \\
\text { gasification }\end{array}$ & $\begin{array}{l}\text { Pressurized formations. } \\
\text { Low density of drilling fluid }\end{array}$ & $\begin{array}{l}\text { Non-productive times. } \\
\text { Additional consumption of } \\
\text { materials and services. } \\
\text { Kicks }\end{array}$ & $\begin{array}{l}\text { Continuous monitoring of } \\
\text { entry-exit fluid flow rates. } \\
\text { Drilling fluid weighting. } \\
\text { Fluid circulation through } \\
\text { degasifier. }\end{array}$ \\
\hline $\begin{array}{l}\text { Pack-offs, } \\
\text { collapse of } \\
\text { borehole }\end{array}$ & $\begin{array}{l}\text { Limestone swelling. } \\
\text { Inadequate specific weight of } \\
\text { drilling fluid. }\end{array}$ & $\begin{array}{l}\text { Non-productive times. } \\
\text { Additional consumption of } \\
\text { materials and services. }\end{array}$ & $\begin{array}{l}\text { Use of products to stabilize } \\
\text { the limestones. }\end{array}$ \\
\hline $\begin{array}{l}\text { Stuck casing } \\
\text { before } \\
\text { reaching final } \\
\text { depth }\end{array}$ & $\begin{array}{l}\text { Pack-off/ collapse of borehole. } \\
\text { Differential sticking. }\end{array}$ & $\begin{array}{l}\text { Non-productive times. } \\
\text { Additional consumption of } \\
\text { materials and services. } \\
\text { Well construction } \\
\text { compromised. }\end{array}$ & $\begin{array}{l}\text { Circulation to remove } \\
\text { detritus. } \\
\text { Continuous casing } \\
\text { reciprocation. }\end{array}$ \\
\hline Casing failure & $\begin{array}{l}\text { Casing pull out from a } \\
\text { connection. } \\
\text { Casing collapse. } \\
\text { Break of casing. } \\
\text { Casing break off. }\end{array}$ & $\begin{array}{l}\text { Non-productive times. } \\
\text { Additional consumption of } \\
\text { materials and services. } \\
\text { Well construction } \\
\text { compromised. }\end{array}$ & $\begin{array}{l}\text { Proper tightening of } \\
\text { connection. Proper casing } \\
\text { sizing. Casing forcing to be } \\
\text { avoided. Complying with } \\
\text { the designed drilling } \\
\text { program. Casing testing at } \\
\text { surface before RIH. }\end{array}$ \\
\hline $\begin{array}{l}\text { Excessive } \\
\text { wear of bit }\end{array}$ & $\begin{array}{l}\text { Selecting an inadequate bit as } \\
\text { compared to formation } \\
\text { hardness. } \\
\text { Improper assessment of rock } \\
\text { hardness. }\end{array}$ & $\begin{array}{l}\text { Failure to reach target, } \\
\text { casing above target, or } \\
\text { withdrawal. }\end{array}$ & $\begin{array}{l}\text { Using such drilling } \\
\text { parameters as } \\
\text { recommended for casing } \\
\text { while drilling. }\end{array}$ \\
\hline
\end{tabular}

\section{Conclusions}

In the context of ever rising costs of well drilling, many of them performed in new geological structures, deep wells, implying a series of geological and technical risks, more and more companies are experimenting and implementing new drilling techniques and technologies with the aim of reducing non-productive times, technical accidents while drilling, and risk mitigation.

Casing while drilling, constantly improving over time, has proven an efficient method to reduce risks, especially those related to the presence of a conventional drill string in the borehole, maintenance of borehole stability or loss of circulation. Moreover, by reducing non-productive times and additional costs to overcome difficulties and technical accidents while drilling, implementation of casing while drilling results in significant cost savings.

\section{References}

1. International Energy Agency, Natural Gas Information: 2018 Overview (IEA, 2018)

2. A. Gligor, Petroleum - Gas University of Ploiesti Bulletin, Technical Series, 68, 3 (2015)

3. C. Frei, World Energy Focus (2017)

4. Weatherford Atlas GIP, Drilling-while-casing (DwC) system. (Bucharest, 2015)

5. N. Macovei, Tubarea si cimentarea sondelor (Editura Universității din Ploiești, 1998)

6. ISO, ISO/Guide 73:2009 - Risk management - Vocabulary (ISO, 2010)

7. ISO, ISO 31010, Risk Management - Risk assessment techniques (ISO, 2010). 